\title{
The Effect of Financial Distress, Company Size, and Audit Quality on The Going Concern Opinion
}

\author{
Santy Setiawan ${ }^{1}$, Rapina $^{2}$, Yenni Carolina ${ }^{3}$, and Kevan Hidayat ${ }^{4}$ \\ 1,2,3,4 Christian Maranatha University \\ 1santy_jc@yahoo.com
}

\begin{abstract}
Since 2020, the Covid-19 pandemic has affected the Indonesian economy and the company's going concern. Therefore, the purpose of this study is to examine the factors that influence an auditor to issue a going concern opinion about a company, particularly the effect of financial distress, company size, and audit quality. Data was collected from property companies listed on the Indonesia Stock Exchange for three years, from 2018 to 2020, using financial statement data. Furthermore, logistic regression was used as the test tool to determine the effect of the independent variable on the dependent. The results showed that financial distress affects going concern opinion, while company size and audit quality do not.
\end{abstract}

Keywords: Keywords: financial, quality, and going concern

$\begin{array}{ll}\text { JEL } & : \text { M42 } \\ \text { DOI } & : 10.24002 / \text { kinerja.v25i2.4795 }\end{array}$

Received : 08/04/2021 Reviewed: 08/09/2021 Final Version: 09/01/2021

\section{INTRODUCTION}

Since 2020, the Covid-19 pandemic has indirectly affected the Indonesian economy and the company's going concern. In the notes to the financial statements, the company is required to disclose how to conduct business during the pandemic. This indirectly affects the audit process, especially the going concern (Nurdin, 2021).

The going concern assumption states that a business entity can survive in a predictable future unless management intends to discontinue its business. However, the level of uncertainty about an event, the complexity and size, including events after reporting or certain future considerations all influence this assumption (IAPI, 2016). 
Paragraph 6 of Auditing Standard Statement (PSA) 30 provides information about the conditions or events that indicate doubts about a company's going concern. The clues can be seen from 1) Negative trends, such as operating losses, less working capital, and poor financial ratios; 2) Difficult indications, such as inability to repay loans, dividends arrears, debt restructuring, and refusal of credit applications; 3) Internal problems, such as strikes, heavy dependence on a project, and uneconomic long-term commitments; and 4) External problems, such as loss of franchise or losses due to disasters (Junaidi and Nurdiono, 2016,pp.16).

An auditor's role is important in providing opinions on financial statements to influence users' decision making, such as concerning the company's going concern. Furthermore, the auditor is expected to state the actual financial condition, especially to users of financial statements, including investors. Conferring a going concern status, which is issued during a company's financial condition decline, is closely related to the reputation of the auditor (Rebeta, 2018).

Cases on going concern can be seen from PT Bakrie Telecom Tbk (BTEL), which previously experienced these problems and has been asked for their opinion on plans (Warenza, 2019). Based on data from the Indonesia Stock Exchange, shares of PT Bakrie Telecom Tbk were suspended seven times between 2016 to 2019 and obtained a disclaimer opinion for two years, 2017 and 2018 (Sidik, 2019).

Mukhtarudin et al. (2018) in a study entitled Financial Condition, Growth, Audit Quality and Going Concern Opinion: Study on Manufacturing Companies Listed on the Indonesia Stock Exchange stated that only financial condition affects this opinion, while company growth and audit quality does not. Meanwhile, Qintharah (2020) in the study entitled "The Effect of Financial Distress and Company Size on Accepting Going Concern Opinion" stated that financial distress has a negative influence, while company size does not.

Based on the phenomenon and previous studies, this study is interested in reexamining the factors influencing going concern opinion, such as financial distress, company size, and audit quality. Financial distress shows the company's condition is declining, thereby causing doubts about its going concern (Agostini, 2018). Furthermore, capital ownership reflects company size because the larger the company, the greater the foreign capital ownership (Halim, 2015). According to Alichia (2013), an auditor more frequently issues these opinions on small companies (Qintharah, 2020). Meanwhile, the competence and independence of auditors reflect their quality.

Consequently, the object of this study demonstrates the difference from previous research. This study focuses on property companies because of a negative trend they experienced during the pandemic, seen from the bankruptcy of PT Cowell Development on July 6, 2020. Bankruptcy in the property sector affects those that provide material products as well as the financial and banking sectors. Therefore, assuming the property sector does not receive attention, the Indonesian economy may face a new crisis (Jannah, 2020). 
Hence, this study aims to identify the effect of financial distress, company size, and audit quality on the going concern opinion.

It is expected to benefits users of financial statements by providing insight into the factors influencing an auditor in issuing a going concern opinion. Also, this serves as reference material for future studies on the factors influencing the issuance.

\section{LITERATURE REVIEW}

\subsection{Financial Distress}

Financial distress can be interpreted as a decrease in financial condition before bankruptcy or liquidation. Assuming the company is already in distress and is not handled properly, it will result in bankruptcy (Hutabarat, 2020, pp. 27-28).

This condition can lead to the company's failure, insolvency, default, and bankruptcy. Failure shows that the rate of return on capital is below similar investments, while insolvency shows poor company performance. Conversely, default occurs during violation of the agreement with the creditor or the inability to complete the payment, while bankruptcy occurs once liabilities exceed a company's (Altman et al., 2019, pp. 6-8).

The failure of companies is usually caused by several factors, namely 1) low operating performance due to international competition and overcapacity; 2) gaps in technological innovation, especially for old companies that must compete with those implementing the latest technology; 3) liquidity and funding shocks due to financial crisis conditions; 4) a fairly high growth rate of new business that increases the risk of failure; 5) deregulation of certain industries that increase competition; and 6) unexpected events that causes material liabilities (Altman et al., 2019, pp. 8-10).

\subsection{Company Size}

The use of capital reveals the company size. Large companies tend to use greater foreign capital because their operations require large funds (Halim, 2015). Meanwhile, small companies tend to have higher working capital than large ones. This is because large companies have (1) increased incentive capital, (2) economies of scale for relatively more stable working capital or cash flows, and (3) better access to financial markets (Hanafi, 2017).

Sources of working capital financing are usually permanent and current. Permanent financing consists of owned capital plus long-term loans in cases where less is available. Meanwhile, current financing is divided into internal and external sources. Internal sources are owned capital consisting of retained earnings, 
sources from outside the company, such as funds from creditors, and owners within the company. This also includes capital from creditors' debts, often called foreign capital. Conversely, external sources are foreign and owned capital (Mulyawan, 2015).

\subsection{Audit Quality}

In practical literature, audit quality is how well the audit conforms to standards. It is interpreted as the auditor's probability of finding and reporting an error or fraud in a client's accounting system. A quality audit is performed by a competent and independent person (Tandiontong, 2016, pp.167).

According to Tandiontong (2016, pp.168), there are two types of audit quality, namely perception, and monitoring. Perception is based on the assessment of other parties, such as the market, and relates to past, rather than actual, performance. According to Watkins et al. (2004), audit quality should be described as the quality or strength of the monitoring performed by the auditor. An auditor, as the "eye" of shareholders, should be able to assure that the financial statements submitted are free from material misstatement.

\subsection{Going Concern Opinion}

In SA 570, the going concern assumption is expressed as an entity's ability to continue in business in the future. The factors influencing this assumption include the level of uncertainty over the event or condition that occurs, the size and complexity of the entity, and considerations about the future based on the available information (IAPI, 2016).

This assumption states that a business entity can survive in a predictable future unless management intends to discontinue its business. However, the level of uncertainty over an event that occurs, the complexity and size of the company, and an event after reporting or certain future considerations all influence this assumption (IAPI: 2016). Arrens (2017) provided several examples of factors influencing going concern opinion, such as the company's operating losses, the inability to pay debts, and the loss of many customers.

The auditor's responsibility is to obtain sufficient and consistent evidence about the appropriateness of management's use of going concern in the preparation and presentation of the financial statements. Additionally, this responsibility includes concluding for material uncertainty about the entity's ability to continue its business. However, there are inherent limitations in detecting material errors because predicting future events or conditions is impossible. Therefore, the auditor's report is not a guarantee of the entity's ability to continue its business (IAPI, 2016). 
The auditor's objectives regarding the going concern assumption are (a) to obtain sufficient appropriate evidence about management's use in the preparation of the financial statements, (b) to conclude based on the evidence obtained for material uncertainty regarding the event or condition that causes the significant doubts about the entity's ability to continue its business, and (c) to determine the impact on the auditor's report (IAPI, 2016).

\subsection{Hypothesis Development}

\subsubsection{Financial Distress and Going Concern Opinion}

Financial distress shows the company's condition is declining and once not handled properly, the company will go bankrupt (Hutabarat, 2020). PSA 30 requires the auditor to issue a warning to financial statements users during doubts about the company's ability to continue the business, at least one accounting period after the financial statements' dates (Purba, 2009, pp.67).

External auditors should be able to identify a company's business failure because this affects determining the right opinion associated with the going concern assumption (Purba, 2009, pp.63). Therefore, the larger the company's financial distress, the greater the probability of issuing the opinion.

Based on the explanation above, this study proposed the following hypothesis: H1: Financial distress affects going concern opinion.

\subsubsection{Company Size and Going Concern Opinion}

Company size can be seen from the capital. A company with larger business operations will tend to own or use larger foreign capital. Assuming the own capital is insufficient to finance the operational costs, foreign capital is used (Halim, 2015). The larger the company, the smaller the probability for the issuance of a going concern opinion.

Based on the explanation above, this study proposed the following hypothesis: H2: Company size affects going concern opinion.

\subsubsection{Audit Quality and Going Concern Opinion}

In the practical literature, audit quality is how well the audit conforms to standards. It is defined as the auditor's probability of finding and reporting an error or fraud in a client's accounting system (Tandiontong, 2016). Good audit quality has a small tendency for issuing a going concern opinion. 
Based on the explanation above, this study proposed the following hypothesis: H3: Audit quality affects going concern opinion.

\section{METHODOLOGY}

\subsection{Study Object}

This study examines the effect of financial distress, company size, and audit quality on going concern opinion. Furthermore, this was performed using the financial data from manufacturing companies listed on the Indonesia Stock Exchange for 3 years, from 2018 to 2020 .

\subsection{Study Data}

Data can be collected directly from sources (primary data) and also from other institutions (secondary data) (Subagyo, 2017). Secondary data such as financial statements and literature studies were used in this study. The financial statements of manufacturing companies were obtained from property companies listed on the Indonesia Stock Exchange through the website www.idx.co.id. Meanwhile, literature studies were used to obtain information about the variables studied.

\subsection{Study Variable}

Independent and dependent variables are used in this study. However, the independent variable influences, while the dependent is influenced (Subagyo, 2017).

The independent variables in this study are financial distress, company size, and audit quality, while the dependent is going concern opinion. Hence, the study model can be described as follows:

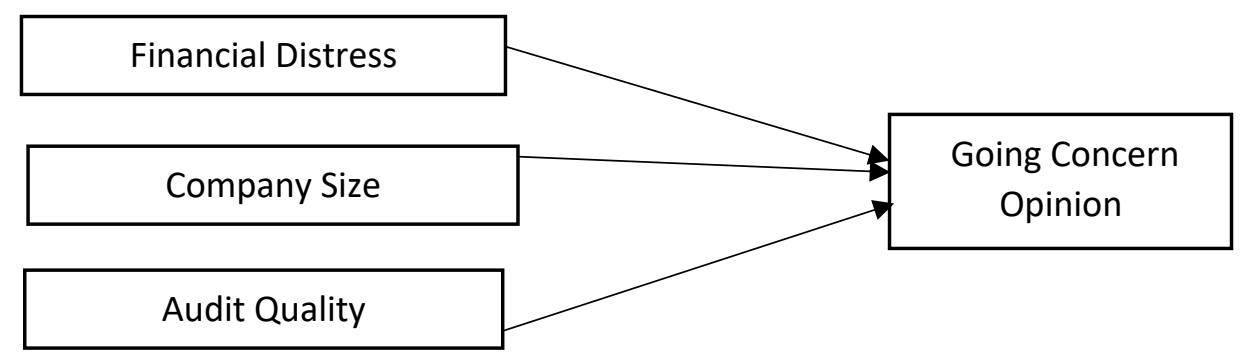

Figure 1. Study Model

Financial distress is defined as a company with negative Earnings Before Interest and Tax (EBIT). This is measured using a dummy variable, with a value of 1 for companies with positive EBIT and 0 for those with negative EBIT. 
Furthermore, company size is measured using total assets owned. Audit quality is measured using a dummy variable, with a value of 1 for companies audited by Big 4 KAPs (Delloite, PwC, EY, and KPMG) and 0 for those not audited by Big 4 KAPs.

Meanwhile, going concern opinion as the dependent variable in this study is measured using a dummy variable, with a value of 1 for companies that receive the opinion and 0 for those that do not.

\subsection{Hypothesis Testing Tool}

This study used a logistic regression test tool because it determines the effect of the independent variable on the occurrence of the dependent. However, it was used for studies with mixed independent variables between continuous (metric) and categorical (non-metric) variables (Ghozali, 2013). The testing steps were as follows (Ghozali, 2013):

1. Assessing Model Fit

The first step was to assess the model's overall fit to the data, and the statistics were used based on the likelihood function. Furthermore, provided the significance value is greater than $5 \%$ the model was said to be fit.

2. Parameter Estimation and Interpretation

Parameter estimation was used to test the effect of each independent variable on the dependent.

\section{RESULT AND DISCUSSION}

\subsection{Hypothesis Testing Results}

For this study data on property companies' financial statements for 3 years from 2018 to 2020 was collected. Subsequently, the property industry sector listed on the Indonesia Stock Exchange was selected based on the criteria for the statements accompanied by independent auditor reports. As study samples, the following are 31 companies engaged in the property industry sector listed on the Indonesia Stock Exchange:

Table 1. Study Sample Data

\begin{tabular}{|l|c|}
\hline \multicolumn{1}{|c|}{ Sample Data } & Total \\
\hline $\begin{array}{l}\text { Property companies listed on the } \\
\text { Indonesia Stock Exchange }\end{array}$ & 31 companies \\
\hline Year of Observation & 3 years \\
\hline Number of samples used & 93 companies \\
\hline
\end{tabular}


Hypothesis testing used Logistics Regression Analysis with 3 independent variables, namely financial distress, company size, and audit quality, and 1 dependent variable, namely going concern opinion. The SPSS test results using Logistics Regression were as follows:

\section{Assessing Model Fit}

The hypotheses for assessing model fit are as follows:

$\mathrm{HO}$ : The hypothesized model fits the data.

$\mathrm{H} 1$ : The hypothesized model does not fit the data.

Table 2. Model Fit

\begin{tabular}{ccccc}
\hline -2 Log & \multicolumn{4}{c}{ Coefficients } \\
\cline { 2 - 5 } likelihood & Constant & FD & UP & KA \\
\hline 79.669 & -3.576 & -1.439 & 0.117 & -0.469 \\
76.377 & -5.688 & -2.046 & 0.193 & -0.843 \\
76.204 & -6.354 & -2.219 & 0.217 & -0.996 \\
76.203 & -6.401 & -2.231 & 0.218 & -1.010 \\
76.203 & -6.402 & -2.231 & 0.218 & -1.010 \\
\hline
\end{tabular}

Omnibus Tests of Model Coefficients

\begin{tabular}{lcccc}
\hline & & Chi-square & df & Sig. \\
\hline Step 1 & Step & 15.184 & 3 & 0.002 \\
& Block & 15.184 & 3 & 0.002 \\
& Model & 15.184 & 3 & 0.002 \\
\hline
\end{tabular}

Based on Table 2, the -2Log Likelihood value was 76.203, indicating that the data was not significant at the $5 \%$ significance level. Hence, Ho was accepted where the hypothesized model fits the data.

\section{Coefficient of Determination}

The following were the test results using SPSS to see the effect of the independent variable on the dependent:

Table 3 Coefficient of Determination

\begin{tabular}{cc|c|c}
\hline Step & $\begin{array}{c}-2 \text { Log } \\
\text { likelihood }\end{array}$ & $\begin{array}{c}\text { Cox \& Snell R } \\
\text { Square }\end{array}$ & $\begin{array}{c}\text { Nagelkerke R } \\
\text { Square }\end{array}$ \\
\hline 1 & 76.203 & 0.151 & 0.241 \\
\hline
\end{tabular}

a. Estimation terminated at iteration number 5 because parameter estimates changed by less than 0.001 .

Based on Table 3, the $\mathrm{R}$ square was 0.241 . This means that the dependent variable (going concern opinion) can be explained by the independent variables 
(financial distress, company size, and audit quality) of $24.1 \%$. Meanwhile, the rest was the effect of other variables outside the study.

3. Goodness of Fit for Study Model

The goodness of fit results for the study model were as follows:

Table 4 Goodness of Fit Test

\begin{tabular}{cccc}
\hline \multicolumn{4}{c}{ Hosmer and Lemeshow Test } \\
\hline Step & Chi-square & df & Sig. \\
\hline 1 & 7.964 & 7 & 0.336 \\
\hline
\end{tabular}

Table 4 was intended to test the null hypothesis that the empirical data fit the model. Provided the significance value is less than 0.05 , the null hypothesis is rejected indicating a significant difference between the model and the observation value. Table 3 shows a significance value greater than 0.05 , hence the null hypothesis was rejected indicating that the model could predict the observation value.

4. Hypothesis testing

The results of hypothesis testing for each independent variable on the dependent were as follows:

Table 5 Hypothesis Testing

\begin{tabular}{lccccccc}
\hline \multicolumn{7}{c}{ Variables in the Equation } \\
\hline \multirow{2}{*}{ Step 1a } & FD & B & S.E. & Wald & df & Sig. & Exp(B) \\
& UP & 0.231 & 0.636 & 12.309 & 1 & 0.000 & 0.107 \\
& KA & -1.010 & 0.221 & 0.972 & 1 & 0.324 & 1.244 \\
& Constant & -6.402 & 6.876 & 1.331 & 1 & 0.249 & 0.364 \\
\hline
\end{tabular}

a. Variable(s) entered on step 1: FD, UP, KA.

Based on table 5, the hypothesis testing results were as follows:

1. Hypothesis 1: Financial distress affects going concern opinion $\rightarrow \mathrm{H} 1$ was accepted $\rightarrow$ the significance value was $0.0005 \%$.

2. Hypothesis 2: Company size affects going concern opinion $\rightarrow \mathrm{H} 2$ was rejected $\rightarrow$ the significance value of $0.324>5 \%$.

3. Hypothesis 3: Audit quality affects going concern opinion $\rightarrow \mathrm{H} 3$ was rejected $\rightarrow$ the significance value of $0.249>5 \%$. 


\subsection{Hypothesis Analysis Results}

The hypothesis testing results can be concluded as follows:

1. Hypothesis 1 was accepted, meaning that financial distress affects going concern opinion. This result was in line with the findings of Qintharah (2020) which shows that financial distress affected the opinion. Furthermore, a bad financial condition signals the company's actual condition to financial statements users.

2. Hypothesis 2 was rejected, meaning that company size does not affect going concern opinion. This result was in line with the findings of Mukhtarudin et al. (2018) and Qintharah (2020). Furthermore, providing the opinion is not only determined by large asset ownership but also bankruptcy which may be experienced by every company especially in a pandemic.

3. Hypothesis 3 was rejected, meaning that audit quality does not affect going concern opinion which was in line with the findings of Mukhtarudin et al. (2018). This is because companies audited by Big 4 and non-Big 4 KAPs will still get the opinion during financial condition decline. Moreover, providing the opinion is influenced by the financial condition rather than the type of KAP that audits a company.

\section{CONCLUSION}

\subsection{Conclusions}

Based on hypothesis testing, several conclusions can be drawn as follows:

1. Financial distress of a company affects giving going concern opinion. A bad financial condition will increase the possibility of issuing the opinion as a warning to financial statements users making business decisions.

2. Company size does not affect providing going concern opinion. This is because every company, especially during a pandemic may experience financial problems or difficulties.

3. Audit quality does not affect providing going concern opinion. This is because it is influenced by the financial condition rather than by the type of public accounting firm (KAP) that audits a company. Assuming the company has problems, the Big 4 and non-Big $4 \mathrm{KAP}$ will give a going concern opinion as a signal for users of financial statements.

\subsection{Suggestions}

This study has several limitations; hence the following suggestions are proposed:

1. Further studies could include a sample of companies engaged in other industries, such as manufacturing and years of observation.

2. Further studies could examine other variables that affect going concern opinion, such as the company's financial condition as measured by financial ratios, previous year's audit opinion, and others. 


\section{REFERENCE}

Agostini, Marisa, 2018. Corporate Financial Distress: Going Concern Evaluation in Both International and U.S.Contexts. Switzerland: Palgrave Pivot.

Altman, Edward I, Edith Hotchkiss, and Wei Wang. 2019. Corporate Financial Distress, Restructuring, and Bankruptcy. New Jersey: John Wiley \& Sons, Inc.

Arrens, Alvin A., Randal J. Elder, Mark S. Beasley, and Chris E. Hogan. 2017. Auditing and Assurance Services. Sixteenth Edition. England: Pearson.

Ghozali, Imam. 2013. Aplikasi Analisis Multivariate dengan Program IBM SPSS 21. Cetakan Ketujuh. Semarang: Universitas Diponegoro.

Halim, Abdul. 2015. Manajemen Keuangan Bisnis-Konsep dan Aplikasinya. Edisi Pertama. Jakarta: Mitra Wacana Media.

Hanafi, Mamduh M. 2017. Manajemen Keuangan. Edisi 2. Yogyakarta: BPFE. Hayes, Rick, Philip Wallage, and Hans Gortemaker. 2017. Prinsip-Prinsip Pengauditan: International Standards on Auditing. Edisi Ketiga. Jakarta: Salemba Empat.

Hutabarat, Francis. 2020. Analisis Kinerja Keuangan Perusahaan. Cetakan Pertama. Jakarta: Desanta Muliavisitama.

Ikatan Akuntan Publik Indonesia. 2016. Standar Profesi Akuntan Publik. Jakarta: Salemba Empat.

Jannah, Selfie Miftahul, 2020. Tren Kepailitan di Sektor Properti Selama Pandemi. [online] Available at: Tren Kepailitan di Sektor Properti Selama Pandemi - Tirto.ID. [Accessed 25 July 2021].

Junaidi dan Nurdiono. 2016. Kualitas Audit: Perspektif Opini Going Concern. Edisi Kesatu. Yogyakarta: Andi Offset, pp. 16.

Mukhtaruddin, Handri Prataman, and Inten Meutia. 2018. Financial Condition, Growth, Audit Quality and Going Concern Opinion: Study on Manufacturing Companies Listed on Indonesia Stock Exchange. Journal of Accounting, Business and Finance Research, Vol. 2, No.1, pp. 16-25.

Mulyawan, Setia. 2015. Manajemen Keuangan. Cetakan 1. Bandung: Pustaka Setia.

Nurdin, Syahdan, 2021. Dampak Covid-19 Terhadap Akuntansi: Pengungkapan dan Audit. [online] Available at: Dampak COVID-19 terhadap Akuntansi: Pengungkapan dan Audit (msn.com) [Accessed 25 July 2021]. 
Purba, Marisi P. 2009. Asumsi Going Concern: Suatu Tinjauan Terhadap Dampak Krisis Keuangan atas Opini Audit dan Laporan Keuangan. Cetakan Pertama. Yogyakarta: Graha IImu.

Qintharah, Yuha Nadhirah. 2020. Pengaruh Financial Distress dan Ukuran Perusahaan Terhadap Penerimaan Opini Audit Going Concern. Prosiding Konferensi Nasional Ekonomi Manajemen dan Akuntansi, 10-11 Desember 2020, Universitas Muhammadiyah Jakarta.

Rebeta, Triana, 2018. Pengaruh Auditor dalam Memberikan Opini Going Concern. [online] Available at: Pengaruh Auditor dalam Memberikan Opini Going Concern (nusantaranews.co). [Accessed 25 July 2021].

Sidik, Syahrizal. 25 Juni 2019. Disuspen 7 Kali dan Nasib Tak Jelas, BEI Panggil Bakrie Telecom. Indonesia: CNBC.

Subagyo, Pangestu. 2017. Statistika Terapan untuk Mahasiswa Ekonomi dan Bisnis. Edisi 1. Yogyakarta: BPFE.

Tandiontong, Mathius. 2016. Kualitas Audit dan Pengukurannya. Cetakan Kesatu. Bandung: Alfabeta.

Warenza, Monica. 10 Juli 2019. Usaha Bakrie Telecom Tak Jelas, Manajemen akan Dipanggil BEI. Indonesia: CNBC. 